\title{
Due to the Law of Marriage Agreement Against Third Party with the Ruling of Constitutional Court Number 69 / PUU-XIII / 2015
}

\author{
$1^{\text {st }}$ Dita Perwitasari \\ Law Department, Faculty of Social \\ Sciences and Law \\ Universitas Negeri Surabaya \\ Surabaya, Indonesia \\ dita.perwitasari@gmail.com
}

\author{
$2^{\text {nd }}$ Eny Sulistyowati \\ Law Department, Faculty of Social \\ Sciences and Law \\ Universitas Negeri Surabaya \\ Surabaya, Indonesia \\ enysulistyowati@unesa.ac.ic
}

\author{
$3^{\text {rd }}$ Indri Fogar Susilowati \\ Law Department, Faculty of Social \\ Sciences and Law \\ Universitas Negeri Surabaya \\ Surabaya, Indonesia \\ indrifogar@unesa.ac.id
}

\begin{abstract}
Marriage Agreement, is something that is still considered taboo for a marriage in Indonesia. However, over time, education levels, technological advances and the current era of globalization are not so taboo to be made in a marriage. The known marriage agreement is a marriage agreement based on the Civil Code and the Compilation of Islamic Laws, in which the Civil Code of Practice shall be made before marriage, whereas in the Compilation of Islamic Law known marriage agreements made before or at the time of marriage take place. If the marriage is done by mixed marriage, where the citizen and foreign citizen is married, then a citizen will lose the right of ownership, either property rights or Building Use Right. This is what triggered the passing of Constitutional Court Decision Number 69 / PUU-XIII / 2015. After the ratification of the Constitutional Court's decision, it will affect not only the two brides (husband and wife) who make a marriage agreement, but also for the third party involved.
\end{abstract}

Keywords- Marriage, Marriage Agreement, Decision of the Constitutional Court

\section{INTRODUCTION}

Marriage, is a legitimate relationship between a man and a woman for a long time. [1] Meanwhile, according to the Compilation of Islamic Law Marriage is marriage, which is a very strong contract or misstaqan ghalidzan to obey the command of God Almighty and implement it is worship. Marriage is one of the ways to continue the family's lineage; However, it has various consequences involving the family itself including husband and wife. [2] Marriage is a legal act concerning the life of the two brides to another party or third party which in the future will certainly be involved in a legal relationship with one of the husband or wives or both. Therefore, if a person wants to marry, of course there are laws and conditions that must be met for the marriage that will become a legal marriage both in terms of religion and state.

Indonesia already has a legal regulation namely Law Number 1 Year 1974 on Marriage, where this law is a unification of the law on marriage. Law Number 1 Year 1974 Concerning Marriage, the principle of separation of property in the presence of joint property or personal property of each party, either husband or wife. As stated in Article 35 paragraph (1) the property acquired during marriage is a common property, whereas in paragraph (2) mentions the property of each husband and wife, and the property acquired as a gift or inheritance, is under as long as its parties do not determine otherwise, meaning that Law Number 1 Year 1974 holds that the property of marriage brought into marriage (property) is still the property of each and the property mixed or obtained after marriage or during marriage is a common property (treasure gono gini). Looks different from the Civil Code (for those marriages subject to the Civil Code), which is mentioned in Article 119 from the time the marriage takes place, then by law apply a unanimous union between husband and wife property.

The marriage agreement, also known as the prenuptial agreement, is known in both marriage laws, which are contained in Law No. 1 of 1974 and there are also rules in the Civil Code. In Law No. 1 of 1974, Article 29 Paragraph (1) mentions a marriage agreement made before or at the time of marriage, in written form with the consent of the parties and ratified by the marriage registry officer, and the contents of the marriage agreement shall apply to a third party that gets stuck. This marriage agreement is valid from the time the marriage is held and the marriage agreement may be changed as long as it is approved by the parties and is made in writing. This is in contrast to what is contained in the Civil Code, wherein a marriage agreement must be made before marriage takes place when a marriage agreement has been established it is not possible to amend the marriage agreement. In Article 139 of the Civil Code stipulates that by marriage agreement between husband and wife is entitled to make some deviations from the law regulation around the unity of property, provided that this agreement does not violate the ethics and public order.

The interesting thing about this marriage agreement is for those who have previously mixed marriage or at the time of marriage does not make a marriage agreement. Mate marriage according to Law Number 1 Year 1974 Article 57 is a marriage between two persons in Indonesia subject to different laws, because of differences in citizenship and one of them is Indonesian citizenship. Mixed marriage if it does not have or make a marriage agreement, then of course will apply the union of property means that the property acquired after and throughout the marriage is a common property and there is no such thing as personal property or property. It must be remembered that if a marriage interferes with the union of property then in the marriage an Indonesian citizen 
will lose the ownership status to the material right, whether in the case of a property or the right to use the building, because it has no marriage agreement, then only joint property and foreigners may not have the right or the right to use the building, if they have the right or the right to use the building, it must relinquish or transfer the right of ownership, as it turns out in Article 21 paragraph (3) and Article 36 paragraph (2) Basic Agrarian Law.

This is what lies behind the petition for judicial review of Law Number 1 Year 1974 concerning Marriage to the Constitutional Court. The Constitutional Court has issued Constitutional Court Decision Number 69 / PUU-XIII / 2015 dated 27 October 2015, which principally granted the petition for judicial review of the terms of the marriage agreement previously set forth in Article 29 paragraph (1), (2), 3) and (4) of Law Number 1 Year 1974 on Marriage, the Constitutional Court in this case granted to the petition petitioned by an Indonesian citizen who is married to a Japanese citizen (a married perpetrator).

This Decision made by the Constitutional Court granted partly to the petition for judicial review of Article 29 paragraph (1) of Law Number 1 Year 1974 concerning Marriage, which is mentioned "At the time, before marriage or during the marriage of both parties to mutual consent may file a written agreement authorized by a marriage or notary, after which the contents are also lodged for a third party. "Whereas in Article 29 paragraph (3) of Law Number 1 Year 1974 on Marriage," the Agreement shall enter into force on the date of marriage unless shall be determined otherwise in the marriage agreement made. "Subsequently to Article 29 paragraph (4) of Law No. 1 of 1974 on Marriage stated" During marriage, marriage agreements may concern marriage or other agreements, irrevocable or revoked, except the consent of both parties u to change or be revoked, and any changes or revocations that exist do not harm a third party.

Certainly in the foregoing can be studied further about the legal consequences of marriage agreement against a third party after the Constitutional Court Decision Number 69 / PUU-XIII / 2015, where it is decided that the marriage agreement can be executed or made during the marriage which ultimately has a major impact on the development of law in Indonesia, especially those related to private law, namely marriage law and ownership of material rights in Indonesia.

\section{RESEARCH METHODS}

The research method used in this writing is the method of juridical legal research. Where normative legal research is conducted by reviewing legislation and other literary materials. This normative research uses the approach of the Act (statute approach) and conceptual approach (conseptual approach). The data used are secondary data which is legal material. The legal substance is the correct information or description of the research object consisting of primary legal material, secondary legal material, and tertiary legal material. [3] This normative jurisdiction is conducted by studying books, literature materials of legislation that support and relate as a legal review of the rules that are considered in accordance with written legal research. This normative study was conducted on theoretical matters of legal principles, legal basis, and legal concepts. [4]

\section{RESULT AND DISCUSSION}

The marriage agreement is a covenantal form, In which the Covenant under the Civil Code of 1313 is an act by which one or more persons commit themselves to one or more persons. It can be interpreted that the marriage agreement is an agreement made and approved by the husband and wife (as the parties), at the time or before the marriage is held to regulate the property and its effects when marriage takes place. In the marriage agreement is generally regulated on property, but also there are other types of marriage agreements that are of course still regulate the wealth that is, about (1) separation of the husband property, meaning the property carried or owned by the husband / wife which it is derived from inheritance, prize, grant, then the property remains the property concerned before marriage takes place, but if after marriage is held the property obtained is included into the joint property, property owned with both husband and wife. (2) separation of profit and loss in marriage, can be interpreted if in marriage happened or there is profit then the profit can be divided directly for both parties, husband / wife. However, if the opposite occurs when there is a loss or demand from a third party (parties outside of the spouse / husband) then the loss will be accounted for by each husband / wife, as it has been written in Article 144 KUHPerdata. (3) the separation of property in full, it can also be interpreted as the mating agreement of this property which is common to be undertaken or made and approved by the parties, whereby all property, whether acquired before marriage or obtained through marriage takes place as property or right of each of the spouses.

1. Marriage Agreement prior to the issuance of Constitutional Court Decision Number 69 / PUU-XIII / 2015

The marriage agreement (Huwdlikse Voorwaarden) is an agreement made by the prospective husband and wife before or at the time of marriage is held to regulate the effects of marriage on their property. [5] There is a difference regarding the making of the marriage agreement contained in the Civil Code and Law Number 1 Year 1974 regarding Marriage. In the Civil Code of the marriage agreement can only be made before the marriage, made by notarial deed and throughout the marriage the marriage agreement takes place cannot be altered in any way (Article 147 of the Civil Code). It seems different even though there is a rule concerning the marriage agreement, it is known in the matter of making the marriage agreement in Law Number 1 Year 1974 regarding Marriage, made in written form, so that it can be made not only by notarial deed but can also be made in writing below hands as long as the parties agree, the mating agreement may be made before or at the time of marriage. In principle, the marriage agreement in Law No. 1 of 1974 during the marriage takes place cannot be changed unless the parties to the agreement agree to change and the changes made do not harm a third party. 
1.1 Due to the Law of the Marriage Agreement against Third Parties

The marriage agreement under the Civil Code shall enter into force at the time of marriage, shall not be specified other than that (Article 147). In the case of registering or registering for a marriage agreement generally takes place shortly after the marriage takes place, only the excerpts of the marriage agreement are registered. The legal consequences arising from the marriage agreement are:

a. The marriage agreement binds both the husband and the wife;

b. The Marriage Agreement also binds to interested third parties;

c. The Agreement may only be changed with the consent of both parties of the husband and the wife, and shall not impair the interests of any third party, nor be authorized by the marriage registry officer. [6]

Against the contents of the marriage agreement the parties may decide what to include in the agreement, this relates to the principle of freedom of contract, provided that it is not contrary to what is stipulated in the law.

The marriage agreement shall be registered or registered by the marriage registry officer, as described in Article 29 paragraph (1) of Law Number 1 Year 1974 that "At the time or before the marriage takes place, both parties to mutual consent may enter into a written then authorized by the marriage registry officer, which then contents are binding on third parties. "

It can be inferred from the above description that there are two important points contained in Article 29 paragraph (1) of Law Number 1 Year 1974 concerning Marriage, namely:

a. That a marriage contract must be registered in order to fulfill the publicity element of the marriage agreement, so that a third party (which is outside the husband's or wife's party) is aware of and is subject to the rules established or existing in the marriage agreement. If there is an unregistered marriage agreement, the marriage agreement will only be binding or applicable to both parties (the spouse / s) making it. This is in accordance with the provisions of Articles 1313, Article 1314 and Article 1340 of the Civil Code, whereby an agreement shall be valid or binding only to the parties making it.

b. Whereas from the moment the marriage law is in effect, the registration, validation or registration of the marriage agreement is no longer on the Registrar's Office of the Court, but for the Muslim couple recording is made at the Office of Religious Affairs (KUA) on his marriage book, and for nonMuslim recording pairs at the local civil registry office on their marriage deed. [7]

Thus it can be said that the marriage agreement will be binding or applicable to any third party involved if the marriage agreement is registered or recorded and authorized in the Office of Religious Affairs (KUA) on their marriage book and for the Muslim and in the local Civil Registry on the marriage certificate they.
2. Marriage Agreement after the issuance of Decision of the Constitutional Court Number 69 / PUU-XIII / 2015

A marriage agreement may be made after or during the marriage, which is closely related to the entry into force of the marriage agreement. Where in Article 29 of the Marriage Law the marriage agreement established at or before the marriage shall take effect from the marriage shall take place. However, after the ratification of the Constitutional Court Decision Number 69 / PUU-XIII / 2015 where it is stated that "The marriage agreement shall come into force since marriage takes place, unless otherwise specified in the marriage agreement." It can be interpreted that a marriage agreement made during or after marriage is held also effective as of marriage, unless there are other provisions of the marriage agreement.

Thus legal consequences to the marriage treaty which came into effect from the marriage took place which was then followed by the status of joint property into a separate property or personal property entirely desired by both parties in the agreement without any further determination of the District Court. Because the marriage agreement that is generally made is a separation agreement of property contained within the principle of freedom of contract, where the parties are given the freedom to regulate what is contained in the contents of the marriage agreement.

2.1 Effects of Marriage Agreement on Third Parties

The Constitutional Court ruling is outlined that the marriage agreement is made in writing in a notarial deed and approved by the marriage registry officer, after which all contents covered by the marriage agreement shall also apply to the third party as long as the third party is involved.

The Marriage Agreement will apply to third parties if the marriage agreement has been authenticated by the Marriage Registry Officer. Generally, third-party have a link with marriage agreement in case of credit agreement. Third party as creditor. In the case of a credit agreement, whereby a third party is a bank there is no marriage agreement then the bank will assume the property of the husband and wife is a joint property and the debt will become a joint responsibility. If it is included with the marriage agreement, then the application of debt will be the responsibility of one of the parties who will apply for credit only, while the other party is not related to the debt in question and has no obligation to participate in paying the debt from their partner. The debt here referred to occurs prior to marriage, during or throughout the marriage, after the divorce even after death.

For married couples Marriage Agreements can be registered at the Office of Religious Affairs on his marriage book. As for non-Muslim marriage or marriage held abroad, the registration of the marriage agreement shall be made at the local Population and Civil Registry Office or on the marriage certificate. Especially for marriages held abroad, it is only done to marriages that have been reported or registered in civil records alone who can register marriage agreements. Without the proof of marriage report of Indonesian Citizens overseas issued by the Office of Population and Civil Registry, the marriage agreement can not be registered or reported. 
Particularly for the recording of marriage agreement reporting in Civil Registry, Circular Letter of the Director General of Population and Civil Registration of the Ministry of Home Affairs Number 472.2 / 5876 / DUKCAPIL dated May 19, 2017 addressed to all Head of Population and Civil Registry (Dukcapil) at Regency / Municipality throughout Indonesia, stipulating that Dukcapil as an executing agency or Technical Implementation Unit (UPT) where there will be marginal notes in the register of deeds and quotations of marriage certificates, while on marriage certificates issued by other countries where the marriage agreement is made in Indonesia, the reporting was made in the form of a certificate. [8]

\section{CONCLUSION}

The Decision Of The Constitutional Court Number 69/ PUU-XIII / 2015 Has Had Major Implications For The Development Of Law In Indonesia, Especially In The Case Of Marriage Law And Of Course Material Rights And Ownership, And Of Course Resulted In Third Parties Involved In Marriage (If Related In Terms Of Marriage Agreement) . Where, This Constitutional Court Decision Relates To A Marriage Agreement Which Can Currently Be Made After Or During The Marriage, Made Before A Notary In The Form Of A Deed Without Having To Be Preceded By The Establishment Of A District Court.

With the enactment of the Constitutional Court ruling which has been binding and permanent law enforcement since it was ratified that this decision applies to all citizens of Indonesia not only to the litigants only (which incidentally is the perpetrator of intermarriage) as well as other institutions or legal entities. Of course, also bind the notaries authorized as officials to make the authentic deed of the marriage agreement, as well as including the office of population and civil records and the Office of Religious Affairs as officials authorized in registering marriage.

Whereas in the Decision of the Constitutional Court Number 69 / PUU-XIII / 2015, it is described the marriage agreement may be made after or during the marriage, performed in writing through notarial deed, valid since marriage is held unless there are other provisions therein, registered or registered by the registrar marriage when a Muslim partner is to be registered by the Office of Religious Affairs (KUA) on his marriage book, while non-Muslim couples will be registered by the Office of Population and Civil Registration on his marriage deed, after which the contents may apply to the third party involved.

\section{ACKNOWLEDGMENT}

Thank you to the Faculty of Social and Legal Sciences for the opportunity to participate in the International Conference on Science and Technology.

\section{REFERENCES}

[2] T. Arsal, "Marriage System in Arabian Culture," 2016

[3] Surjono Sukanto \& Sri Mamuji, Penelitian Hukum Normatif. Jakarta: PT. Raja Grafindo Persada, 2012.

[4] A. K. Muhammad, Hukum dan Penelitian Hukum. Bandung: PT. Citra Aditya Bakti, 2004.

[5] R. S. Prawirohamidjojo, Pluralisme dalam Perundang-undangan Perkawinan di Indonesia. Surabaya: Airlangga University Press, 1988.

[6] A. K. Muhammad, "Hukum Perdata Indonesia," p. 99, 2014.

[7] I. Devita Purnamasari, "Sahkah Perjanjian Kawin Yang Tidak Didaftarkan Ke Pengadilan," Http://m.hukumonline.com, 2013. [Online]. Available: http://www.hukumonline.com/klinik/detail/lt525dffe353c5e/sahk ah-perjanjian-kawin-yang-tak-didaftarkan-ke-pengadilan.

[8] Nirmala, "DAMPAK PUTUSAN MAHKAMAH KONSTITUSI NO. NO. 69/PUU/XII/2015 TERHADAP HUKUM PERKAWINAN DAN HAK KEBENDAAN DI INDONESIA," Http://business-law.binus.ac.id, 2017. [Online]. Available: http://business-law.binus.ac.id/2017/05/31/dampak-putusanmahkamah-konstitusi-no-no-69puuxii2015-terhadap-hukumperkawinan-dan-hak-kebendaan-di-indonesia/. 